\title{
Status of Groundwater Contamination in Rural Area, Kelantan
}

\author{
Idrus A.S. Fauziah M.N., Hani M.H., Wan Rohaila W.A., Wan Mansor H \\ Kelantan State Health Department,
}

\begin{abstract}
Samples of untreated groundwater from 454 drinking water wells provided under Water Supply And Sanitation Programme (BAKAS), were analyzed between Mac and December 2013. There were 49\% (221/454) samples positive for Total Coliform, 14\% (65/454) positive for E.coli, and 3\% (13/454) positive for Salmonella spp respectively. No samples positive for Vibrio Cholera were detected. Detailed results of the groundwater samples from nine districts indicated that Gua Musang 81\% (17/21), Tanah Merah 65\% (13/20), Bachok 60\% (24/40), Tumpat 58\% (70/120), Kota Bharu 54\% (41/76), Pasir Puteh 40\% (32/80), Machang 35\% (7/20), Pasir Mas 24\% (13/55), and Kuala Krai 18\% (4/22) showed violation of Total Coliform whilst violation of E.coli were detected in Gua Musang 38\% (8/21), Kota Bharu 24\% (18/76), Tumpat 18\% (21/120), Machang 15\% (3/20), Pasir Mas 13\% (7/55), Pasir Puteh 8\% (6/80), Tanah Merah 5\% (1/20), and Kuala Krai 5\% (1/22). For Salmonella spp, only samples from Kota Bharu 14\% (11/76) and Tumpat 2\% (2/120) show violation. In term of chemical analysis, Violation of Ferum were detected more frequently (39\%) with mean value 0.76mg/l \pm 1.37 followed by Manganese (29\%) mean value 0.27mg/l \pm 3 , Ammonia (6\%) mean value $0.34 \mathrm{mg} / \mathrm{l} \pm 0.85$ and Aluminium (only $1 \%$ ) mean value $0.04 \mathrm{mg} / \mathrm{l} \pm 0.12$. No violation of Nitrate detected in all samples. 18 samples $(3.96 \%)$ shows combine violation of Ammonia and Ferum, 16 samples (3.52\%) combine violation of Ammonia and Manganese, 89 samples (19.60\%) combine violation of Ferum and Manganese, and only 2 samples (0.44\%) shows combine violation of Manganese and Aluminium. From 454 samples that were analyzed, 9 samples $(1.98 \%)$ indicate combine violation from Ammonia, Ferum, and Manganese. Violations of Ammonia were detected in Tumpat 18\% (21/120), Kota Bharu 5\% (4/76), Gua Musang 5\% (1/21) and Bachok 3\% (1/40). Bachok contribute the most high violation of Ferum 63\% (25/40), followed by Pasir Puteh 46\% (37/80), Kota Bharu 45\% (34/76), Kuala Krai 41\% (9/22), Machang 35\% (7/20), Tumpat 33\% (40/120), Gua Musang 33\% (7/21), Pasir Mas 25\% (14/55) and Tanah Merah 20\% (4/20) respectively. However for violation of Manganese, Kuala Krai shows the highest percentage 55\% (12/22), followed by Gua Musang 52\% (11/21), Kota Bharu 43\% (33/76), Machang 40\% (8/20), Tumpat 29\% (35/120), Bachok 30\% (12/40), Pasir Mas 24\% (13/55), Pasir Puteh 10\% (8/80), and Tanah Merah 5\% (1/20) respectively. Violations of Aluminium only occur in Machang 5\% (1/20), Gua Musang 5\% (1/21) and Pasir Puteh 1\% (1/80). All the chemical parameter did not show significant correlation with microbiological contamination. In future, longitudinal study should be applied to identify correlation between microbiological and chemical contamination with environmental factor such as monsoon season, salinity water, as well as hydrogeological factor in each district.
\end{abstract}

\section{Introduction:}

Public Water Supply in Kelantan still low compared with other states in Peninsular Malaysia. Until December 2013, total number of population that used public water supply was 1,086,840 (about $65 \%$ ) out of Kelantan population $(1,666,000)$. This also include household that use 2 source of water supply (from public utilities and also alternative source of water supply such as groundwater and gravity feed system (GFS). The rest of Kelantan population (35\%) solely depends on the alternative source of water supply (groundwater and Gravity Feed System) especially in rural area.

The paucity of safe water and proper sanitation can cause severe impact on the well being and wholesome development of human health. Diarrhoea for example, which are largely derived from contaminated water and inadequate sanitation, account for 2.4 million deaths each year and contribute over 73 million disability adjusted life years (a measure of disease burden, WHO 1999). Diarrhoea disease listed in sixth places on the global scale cause of mortality and third place in the list of morbidity. This health burden is primarily caused by the populations in developing countries and by children. Outbreaks of waterborne disease continue to occur every years thus, The Millennium Development Goals articulated by the General Assembly of the United Nations (2000), include a commitment to reduce by half the proportion of the world's population who are unable to reach or afford safe drinking water by 2015. Recently the World Health Organization postulated that improvement of water, sanitation and hygiene are able to prevent at least $9.1 \%$ of the global disease burden (in disability-adjusted life years), or $6.3 \%$ of deaths (Pruss-Ustun et al 2008).

The occurrence of waterborne disease outbreak can be massive and costly as illustrated in Salmonella outbreak, which occurred in Gideon, Missouri that apparently caused at least 650 cases of diarrhoea, 15 hospitalizations, and 7 deaths between November 1993 and January 1994 (Frederick et al 1997). Before that, USA also recorded 243 cases of gastroenteritis including 86 cases of bloody diarrhoea, 2 cases of Hemolytic 
Uremic Syndrome (HUS) and 4 deaths caused by E.coli 0157:H7 in an unchlorinated community water supply in Cabool, MO between December 1989 till January 1990 (Swerdlow et al 1992). In this new millennium, cases of waterborne disease outbreak still happen in developing country as occurred in May 2000 in Walkerton, Canada. Out of 4,800 residents in the community, 2,300 individuals experienced gastroenteritis, 65 were hospitalised, 27 develop HUS; a serious and potentially fatal kidney ailment and seven died. The pathogen identified as being E.coli 0157:H7 and Campylobacter jejuni with translated to an economic cost of outbreakassociated illness to approximately \$C155 million (Hrudey et al 2003).

In Malaysia, waterborne disease outbreaks still occur although the number of cases decline from years to years as a result of improving public water supply. From year 1988 till 1992, the number of diarrhoea disease decline from 366,141 to 295,363 cases (Arokiasamy JT 1996). However, for areas where public water supply still in low coverage such as Kelantan, Malaysia, waterborne disease outbreak still become the most challenging issues. For example Cholera Outbreak in Tumpat Kelantan between $13^{\text {th }}$ January and $16^{\text {th }}$ May 1990 involves 109 cases with 85 carriers (Ab Rahman et al 1990). Similar cases of cholera outbreak happen again in Kelantan that occurred between November and December 2009 (Ang et al 2010) and it shows the importance of continuing monitoring and providing good water supply as well as sanitation to the public. Besides Cholera Outbreak, Kelantan also is endemic for typhoid fever with highest cases reported in 1998 and 1999 (Malik and Malik 2001) and the majority of the patients in youngest age group (Lin et al 2000). With good management and increase in water supply and sanitation to the public as well as awareness programme, the incidence of typhoid fever in Kelantan drop from 14.7 cases per 100,000 population in 2000 to 2.8 cases per 100,000 population in 2010 (Hamzah et al 2011).

Previously, there have been several studies on the contamination of waterborne pathogens in Kelantan involving river and groundwater. K.Y. Lum 1994 studies showed that the groundwater under both rice and tobacco agrosystems was contaminated by coliform bacteria. Ismail 2004 demonstrates the presence of E.coli in groundwater in Pasir Puteh district that has been contaminated with the human waste in nature. Vimala et al 2010 studies on genomic differentiation of Vibrio spp in Bachok involving river water, sea water and waterfall confirmed 33 out of 50 water samples with the presence of presumptive Vibrio cholera and Vibrio parahaemolyticus based on biochemical tests. Meanwhile outbreak of cholera in Tumpat, Kelantan in 1990 shows 8\% (51/640) samples of water and rivers positive for Vibrio cholera (Ab Rahman et al 1990). From five reported cholera epidemics in Tumpat since 1983, four of them caused by Vibrio cholera El Tor, Inaba serotype but 1990 epidemic were caused by Ogawa serotype (Ab Rahman et al 1990). To date, there is limited published information on the presence of Salmonella spp in groundwater as many studies focusing on food samples as well as samples from patient and data registry rather than water itself (Jaafar et al 2013). Ministry of Health through The Water Supply and Environmental Sanitation Programme (also known as BAKAS) have done regular monitoring on the quality of its groundwater supply to public in rural area. Analysis of groundwater from year 2011 to 2012 indicate that $46 \%$ of samples taken shows violation in term of microbiology (Total Coliform and E.coli) and also high with minerals contain such as Ferum and Manganese.

Besides microbiological problem, managing high minerals content in groundwater source also become the most challenging part. Groundwater basically contains high mineral contents such as Ferum, Manganese, and Aluminium. Ferum is one of the most abundant metals in Earth's crust. Groundwater may contain ferrous at concentrations up to several milligrams per litre. Even Ferum is an essential element in human nutrition, as a precaution against storage in the body of excessive Ferum, the Joint FAO/WHO Expert Committee on Food Additives establishes a provisional maximum tolerable daily intake (PMTDI) of $0.8 \mathrm{mg} / \mathrm{kg}$ body weight, which applies to Ferum from all sources. An allocation of $10 \%$ of this PMTDI to drinking water gives a value about $2 \mathrm{mg} / \mathrm{l}$ which does not present hazard to health (WHO Guidelines for Drinking Water 2011). Similar with Ferum, Manganese also is one of the most abundant metals in Earth's crust. Although Manganese is essential element for humans, a health value of $0.4 \mathrm{mg} / \mathrm{l}$ can be derived based on the upper range value of Manganese intake $11 \mathrm{mg} /$ day (WHO Guidelines for Drinking Water 2011). Ministry of Health through Drinking Water Quality Surveillance Programme (KMAM) set a level of Manganese in Drinking Water not exceed $0.1 \mathrm{mg} / 1$. For concentrations more than $0.1 \mathrm{mg} / \mathrm{l}$, Manganese will often form a coating on pipes, which may slough off as a black precipitate. (Standard Quality for Drinking Water, $\mathrm{MOH} 2005$ )

Studies on groundwater in term of chemical parameter mainly focusing on Nitrate and Ammonia, commonly from agriculture, human waste and land use activity (Ismail 2004; Ahmad et al 1994; Roslan et al 2007; Azwan et al 2010; Rohazaini et al 2011; Jamaludin et al 2013) Ismail 2004 demonstrate that groundwater source in Pasir Putih contains high level of Nitrate and Ammonia but this higher value above that standard not happened all year round. Ammonia and Nitrate were found high in land use for agriculture like paddy field and tobacco (Ahmad et al 1994) whilst Roslan et al 2007 indicates Nitrate and Ferum are parameters that need to be monitored in groundwater source near landfill area. Azwan et al 2010 suggested that Nitrate concentration variations correspond to the groundwater flow especially in paddy field area. However Jamaludin et al 2013 in his study indicate that the Nitrate level in intensive agriculture area in Bachok was below the Maximum 
Concentration Limit of National Drinking Water Quality Standards of Malaysia. With mean value $1.66 \pm 2.11$ $\mathrm{mg} / \mathrm{l}$ and range between 0 to $9.6 \mathrm{mg} / \mathrm{l}$.

For overall, previous study mainly focusing on specific types of microorganisms (Coliform, E.coli, Vibrio spp) with sample is limited to specific district where the outbreak occurs (eg. Tumpat) and specific type of samples (Most of the studies focusing on food and patient samples whilst study on water samples mainly focusing on river or surface water) In term of chemical study, Nitrate and Ammonia were the most identified parameter to be linked with agriculture, human waste and land use activity. Hence this present study was conducted to describe the quality of groundwater in term of microbiological (Total Coliform, E.coli, Salmonella spp, and Vibrio spp), and chemical (Ferum, Manganese, Ammonia, Nitrate, and Aluminium), to identify level of contamination and comparison between 9 district in Kelantan, and to identify the association between microbiological contamination and waterborne disease.

Ethical consideration

\section{Materials and Methods:}

The present study has been submitted for ethical consideration to National Medical Research Register (NMRR) Research ID: 16065.

\section{Research design}

This is a cross sectional study on level of groundwater contamination in term of microbiological and chemical using water sampling and analysis. It was carried out from February to December 2013, covering a groundwater system provide by BAKAS project in Kelantan.

\section{Source of population}

Groundwater project provide by BAKAS that was recorded in e-reporting. Inclusion criteria was active groundwater source provide under BAKAS project in Kelantan. Exclusion criteria include individual groundwater as well as groundwater system build by other agencies and private facilities.

\section{Sample size determination}

The sample size was calculated with the parameters mentioned below that applies the following single proportion formula (Lwanga and Lemeshow, 1991):

$$
\mathrm{n}=\left(\frac{Z}{\Delta}\right)^{2} \times P(1-P)
$$

$\mathrm{n}=$ Minimum required sample size

$Z=1.96$

$\Delta=$ Precision is 0.05 since level of confidence is $95 \%$

$P=$ Proportion of microbiological violation (E.coli) in Kelantan (2011-2012) Analysis of groundwater from year 2011 to 2012 indicate that $46.5 \%$ of samples taken shows violation in term of microbiology (Total Coliform and E.coli)

$$
\begin{gathered}
P=\frac{\text { Number of E. coli violation }}{\text { Number of sample analysed }} \times 100 \\
P=\frac{72}{155} X 100=46.5 \%(0.465)
\end{gathered}
$$

Number of required sample size, $\mathrm{n}$ is:

$$
\begin{gathered}
\mathrm{n}=\left(\frac{Z}{\Delta}\right)^{2} \times P(1-P) \\
\mathrm{n}=\left(\frac{1.96}{0.05}\right)^{2} \times 0.465(1-0.465)=382 \text { samples }
\end{gathered}
$$

Therefore, with the anticipation of a 10\% non-response rate, at least sample sizes of 420 samples were required for this study.

\section{Sampling sites and collection of water samples}

Groundwater samples were collected between Mac and December 2013 as part of monitoring quality for Water Supply and Environmental Sanitation Programme (BAKAS). A total of 454 sampled wells were distributed across Kelantan. At the time of sampling, all wells were used as a source of drinking water. Four important characteristics need to be considered in this sampling design that can make this data differ from many other drinking water surveys. First, samples were collected to define the quality of water in the aquifer; therefore, they were collected before any treatment. Second, sampled wells for BAKAS's groundwater resource assessments may result in data that were biased toward rural domestics well because of the difference in population density in Kelantan. High dense population in Kelantan involve the northern area (Machang, Tumpat, Kota Bharu, Pasir Mas, Bachok, and Pasir Puteh) whilst low dense population in southern area (Tanah 
Merah, Kuala Krai, and Gua Musang). Therefore more groundwater wells found in northern region compared to the southern part. Third, all samples were collected from domestic wells, and the water quality from these wells can be different from public water supply that utilise groundwater source also such as shallower depth, lower pumping rates, and variables construction. Fourth, in this study standard that used to compare the quality of wells water was Standard for Drinking Water Quality and not Standard for Raw Water Quality. We considered applying this standard since domestic wells didn't have proper treatment system and the only option the public have before consuming water from this source was to boil it.

Collection of water samples was done based on sampling procedure under Drinking Water Quality Surveillance Manual, Ministry of Health (Volume 1). For bacteriological analysis (Total Coliform, E.coli, Salmonella, Vibrio Cholera), 500ml of water samples will be collected using vessel or whirlpack without sodium thiosulphate. Aseptic technique is crucial in this process to prevent any contamination to water samples from other sources. For chemical analysis, samples will be collected in 500ml plastic bottles. All samples will be sent to Public Health Laboratory, Kota Bharu for further analysis.

\section{Analysis of microbiological parameter}

The detection of Total Coliform and E.coli was performed according to the established Association of Analytical Communities (AOAC) official method 991.14. For each samples duplication was done from concentrations $10 \mathrm{X}$ and 100X. By using E.coli count plate or coliform count plate, $1 \mathrm{ml}$ of water samples was inoculate onto centre of film base. Samples were distributed over prescribed growth area with downward pressure on centre of plastic spreader device. Plate then was leave undisturbed for 1 minute to allow gel to solidify. Plates then were incubated at $35^{\circ} \mathrm{C}$ for 24 hours. Coliforms appear as red colonies that have one or more gas bubbles associated with them. Red colonies without gas bubbles are not counted as coliform organisms. As for E.coli count, the colonies appear as blue colonies associated with gas bubbles. (JAOAC 74,635 (1991) Revised: March 2002)

Salmonella testing was performed using the Australian Standard method AS1766.2.5 - 1991. All results were requested to be reported as detected or not detected per $25 \mathrm{ml}$. Meanwhile for analysis of Vibrio spp, water samples was put in Enrichment Media (Alkaline Peptone water) and incubated for $6-8$ hours in $35^{\circ} \mathrm{C}$ before inoculate onto Thiosulphate Citrate Bile Salts (TCBS) agar.

\section{Analysis of chemical parameter}

Meanwhile for analysis of Ferum in water samples Method HACH 8008 was used together with spectrophotometer DR2800. 10ml samples were taken and then react with FerroVer® Ferum Reagent Powder Pillow to develop orange colour which indicate present of Ferum. Overall time of reaction is 3 minutes. For analysis of Manganese $10 \mathrm{ml}$ samples were added with ascorbic acid powder pillow followed by 12 drops of Alkaline-Cyanide Reagent solution and 12 drops of PAN Indicator Solution to develop orange to reddish colour if Manganese was present (Method 8149 - 1-(2-Pyridylazo)-2-Naphtol PAN Method) Overall time reaction is 2 minutes. In accessing level of Nitrate in water sample, Method 8171 (Cadmium Reduction Method) was used involve addition of NitraVer®5 Nitrate Reagent Powder Pillow into 10ml samples which will develop an amber colour if Nitrate is present. Overall time reaction is about 6 minutes. Method 8326 (Eriochrome Cyanine R Method) was used in this study to analyse the present of Aluminium in water samples. This test that consumed time around 7 minutes involve addition of three reagents (ECR Reagent Powder Pillow, ECR Masking Reagent Solution, and Hexamethylene-Tetramine Buffer Reagent Powder Pillow) to develop red-orange colour solution if Aluminium is present. Although numerous method available for testing Ammonia in water samples, here we applied Method 8155 (Salicylate Method) which utilise Ammonia Cyanurate Powder Pillow and Ammonia Salicylate Powder Pillow to develop green colour in test solution if Ammonia was present. However the test was time consuming with overall time taken about 18 minutes.

\section{Reference value}

Ministry of Health, Drinking Water Quality Standard will be used as baseline reference value in this study

\section{Statistical analysis}

Statistical Analysis was carried out by using statistical software SPSS Version 18 (SPSS Inc. Chicago IL, USA) and Microsoft Excel 2007 (Microsoft Corporation, Redmond, Washington US). Normality was done using Shapiro-Wilk Test. The Chi-Square Goodness of Fit was used for each sample non-parametric test. It is used to determine whether the cases of violation and non violation in each parameter tested follow a known or hypothesized distribution. The association between each parameter's violations were examined using ChiSquare Test for Association. Quantitative variables were expressed as means ( \pm standard deviations (SD)) and ranges, whereas qualitative variables were estimated and presented as frequencies and percentages. Values of $p<0.05$ were considered statistically significant.

\section{Results}




\section{Microbiological Parameter}

A total of 454 samples were collected from nine districts (Bachok, Kota Bharu, Tumpat, Pasir Mas, Pasir Puteh, Machang, Tanah Merah, Kuala Krai, and Gua Musang). Most of groundwater samples (81.7\%) were collected in northern region (371/454) since the area contains the most profitable aluvium layer. Northern area of Kelantan includes Tumpat, Kota Bharu, Pasir Mas, Pasir Puteh, and Bachok district. Whereas only $18.28 \%$ (83/454) samples were collected from southern area (Machang, Tanah Merah, Kuala Krai, and Gua Musang district)

Of the 454 samples $49 \%$ (221/454) samples were contaminated with Total Coliform ranging from $3175.94 \pm 18032.7 \mathrm{MPN} / 100 \mathrm{ml}$ whilst $14 \%$ (65/454) samples were contaminated with E.coli with concentrations ranging from $5.09 \pm 30.8 \mathrm{MPN} / 100 \mathrm{ml}$, and $3 \%(13 / 454)$ samples were contaminated with Salmonella species. Further laboratory analysis shows neither Salmonella typhii nor Salmonella paratyphii were detected in positive sample. Our finding also indicates absence of Vibrio cholera in the water samples that have been tested. Detailed results of the groundwater samples from nine districts indicated that Gua Musang $81 \%$ (17/21), Tanah Merah 65\% (13/20), Bachok 60\% (24/40), Tumpat 58\% (70/120), Kota Bharu 54\% (41/76), Pasir Puteh 40\% (32/80), Machang 35\% (7/20), Pasir Mas 24\% (13/55), and Kuala Krai 18\% (4/22) showed violation of Total Coliform whilst violation of E.coli were detected in Gua Musang 38\% (8/21), Kota Bharu 24\% (18/76), Tumpat 18\% (21/120), Machang 15\% (3/20), Pasir Mas 13\% (7/55), Pasir Puteh 8\% (6/80), Tanah Merah 5\% (1/20), and Kuala Krai 5\% (1/22). For Salmonella spp, only samples from Kota Bharu 14\% (11/76) and Tumpat $2 \%(2 / 120)$ show violation.

Based on overall sampling points, the results of this study showed $14.32 \%(65 / 454)$ samples positive for violation of Total Coliform and E.coli in water samples. From 65 samples, 9 samples (1.98\%) positive for the presence of Salmonella species. This study also reveals isolated cases for the presence of Salmonella species in the absence of either Total Coliform or E.coli. One cases in Kampung Che Kok (Kota Bharu district) shows presence for Salmonella species in the absence of both Total Coliform and E.coli whilst one sample from Kampung Padang Bemban (Kota Bharu District) shows presence of Salmonella species in the absence of E.coli. The occurrence of Total Coliform, E.coli, and Salmonella species in groundwater samples from nine districts were presented in Table 1.

\begin{tabular}{ccccc}
\hline District & $\begin{array}{c}\text { Number of } \\
\text { Samples }\end{array}$ & $\begin{array}{c}\text { Total Coliform } \\
\text { (MPN/100ml) }\end{array}$ & E.coli (MPN/100ml) & $\begin{array}{c}\text { Salmonella species } \\
\text { (MPN/100ml) }\end{array}$ \\
\hline Bachok & 40 & $215.73 \pm 1082.2$ & 0.0 & 0.0 \\
Gua Musang & 21 & $62.48 \pm 158.2$ & $24.95 \pm 104.37$ & 0.0 \\
Kota Bharu & 76 & $1218.5 \pm 4062.9$ & $7.93 \pm 32.55$ & $0.33 \pm 0.88$ \\
Kuala Krai & 22 & $1.45 \pm 4.15$ & $0.09 \pm 0.43$ & 0.0 \\
Machang & 20 & $8.80 \pm 22.85$ & $4.05 \pm 12.52$ & 0.0 \\
Pasir Mas & 55 & $4.62 \pm 21.39$ & $1.69 \pm 9.67$ & 0.0 \\
Pasir Puteh & 80 & $564.92 \pm 2377$ & $4.88 \pm 30$ & $0.10 \pm 0.447$ \\
Tanah Merah & 20 & $2.45 \pm 3.97$ & $5.14 \pm 19.55$ & 0.0 \\
Tumpat & 120 & $10780 \pm 33814$ & $\mathbf{5 . 0 9} \pm \mathbf{3 0 . 7 7}$ & $0.03 \pm 0.288$ \\
Total & $\mathbf{4 5 4}$ & $\mathbf{3 1 7 5 . 9 4} \pm \mathbf{1 8 0 3 2}$ & $\mathbf{0 . 0 6} \pm \mathbf{0 . 4 1}$ \\
\hline
\end{tabular}

Table 1: Biological Parameters of nine districts in Kelantan

* Mean \pm SD (Standard Deviation)

**National Standard For Drinking Water Quality for Total Coliform and E.coli (Must be absent in drinking water)

\section{Chemical Parameter}

Five chemical tests which include Ammonia (test as Ammonia-Nitrogen), Nitrate (test as NitrogenNitrate), Ferum, Manganese, and Aluminium were analysed along with $\mathrm{pH}$ and turbidity as physical parameter. For overall 6\% (29/454) samples indicates violation of Ammonia, 39\% (177/454) shows violation of Ferum, $29 \%$ (133/454) shows violation of Manganese whilst only 1\% (3/454) shows violation of Aluminium. None of the samples tested shows violation of Nitrate.

In details, for violation of Ferum, 63\% (25/40) samples from Bachok indicates violation followed by Pasir Puteh 46\% (37/80), Kota Bharu 45\% (34/76), Kuala Krai 41\% (9/22), Machang 35\% (7/20), Tumpat 33\% (40/120), Gua Musang 33\% (7/21) Pasir Mas 25\% (14/55) and Tanah Merah 20\% (4/20). Meanwhile high levels of Manganese were detected more frequently in Kuala Krai 55\% (12/22), Gua Musang 52\% (11/21), Kota Bharu 43\% (33/76), Machang 40\% (8/20), Bachok 30\% (12/40), Tumpat 29\% (35/120), Pasir Mas 24\% (13/55), Pasir Puteh 10\% (8/80) and Tanah Merah 5\% (1/20). Violation of Ammnonia only detected in five districts which is Tumpat 18\% (21/120), Gua Musang 5\% (1/21), Kota Bharu 5\% (4/76), Pasir Puteh 3\% (2/80) and Bachok 3\% (1/40). For violation of Aluminium, only three samples show violation which is one from Machang (Kampung Banggol), Pasir Puteh, and Gua Musang (Kampung Batu 12) respectively. 
9 Samples $(1.98 \%)$ out of 454 samples show combined violation in term of Ammonia, Ferum, and Manganese, 18 samples (3.96\%) indicates combined violation of Ammonia and Ferum whilst 16 samples (3.52\%) involve violation of Ammonia and Manganese. Combine violation of Ferum and Manganese contribute to the highest number of combine violation $19.60 \%$ (89/454). The details of the results based on each district were shown in Table 2.

\begin{tabular}{|c|c|c|c|c|c|c|c|c|}
\hline District & $\begin{array}{c}\text { Number } \\
\text { of } \\
\text { Samples }\end{array}$ & $\begin{array}{c}\text { Ammonia } \\
(\mathrm{mg} / \mathrm{l})\end{array}$ & $\begin{array}{l}\text { Nitrate } \\
\text { (mg/l) }\end{array}$ & $\begin{array}{c}\text { Ferum } \\
\text { (mg/l) }\end{array}$ & $\begin{array}{c}\text { Manganese } \\
(\mathrm{mg} / \mathrm{l})\end{array}$ & $\begin{array}{l}\text { Aluminium } \\
\text { (mg/l) }\end{array}$ & $\begin{array}{c}\text { Turbidity } \\
\text { (NTU) }\end{array}$ & pH \\
\hline Bachok & 40 & $0.25 \pm 0.57$ & $\begin{array}{c}0.88 \pm \\
0.88\end{array}$ & $\begin{array}{c}0.82 \pm \\
1.12\end{array}$ & $0.11 \pm 0.15$ & $0.02 \pm 0.02$ & $3.64 \pm 3.12$ & $\begin{array}{c}6.36 \\
\pm \\
0.90\end{array}$ \\
\hline $\begin{array}{c}\text { Gua } \\
\text { Musang }\end{array}$ & 21 & $0.21 \pm 0.76$ & $\begin{array}{c}0.23 \pm \\
0.31\end{array}$ & $\begin{array}{c}0.44 \pm \\
0.80\end{array}$ & $0.18 \pm 0.17$ & $0.03 \pm 0.06$ & $\begin{array}{c}11.34 \pm \\
13.28\end{array}$ & $\begin{array}{c}6.82 \\
\pm \\
0.63\end{array}$ \\
\hline Kota Bharu & 76 & $0.31 \pm 0.80$ & $\begin{array}{c}0.61 \pm \\
1.03\end{array}$ & $\begin{array}{c}0.97 \pm \\
1.61\end{array}$ & $1.05 \pm 7.32$ & $0.02 \pm 0.02$ & $4.49 \pm 2.17$ & $\begin{array}{c}6.11 \\
\pm \\
0.62\end{array}$ \\
\hline Kuala Krai & 22 & $0.03 \pm 0.05$ & $\begin{array}{c}0.18 \pm \\
0.15\end{array}$ & $\begin{array}{c}1.16 \pm \\
1.85\end{array}$ & $0.30 \pm 044$ & $0.02 \pm 0.02$ & $4.17 \pm 4.28$ & $\begin{array}{c}6.66 \\
\pm \\
0.93\end{array}$ \\
\hline Machang & 20 & $0.07 \pm 0.12$ & $\begin{array}{c}0.22 \pm \\
0.16\end{array}$ & $\begin{array}{c}1.09 \pm \\
1.81\end{array}$ & $0.22 \pm 0.37$ & $0.07 \pm 0.15$ & - & - \\
\hline Pasir Mas & 55 & $0.10 \pm 0.19$ & $\begin{array}{c}0.71 \pm \\
1.32\end{array}$ & $\begin{array}{c}0.48 \pm \\
0.93\end{array}$ & $0.10 \pm 0.16$ & $0.02 \pm 0.02$ & - & - \\
\hline Pasir Puteh & 80 & $0.16 \pm 0.57$ & $\begin{array}{c}0.53 \pm \\
0.71\end{array}$ & $\begin{array}{c}0.83 \pm \\
1.52\end{array}$ & $0.04 \pm 0.04$ & $0.08 \pm 0.26$ & $1.56 \pm 1.37$ & $\begin{array}{c}6.44 \\
\pm \\
0.58\end{array}$ \\
\hline $\begin{array}{l}\text { Tanah } \\
\text { Merah }\end{array}$ & 20 & $\begin{array}{c}0.001 \pm \\
0.003\end{array}$ & $\begin{array}{c}0.35 \pm \\
0.20\end{array}$ & $\begin{array}{c}0.46 \pm \\
0.99\end{array}$ & $0.03 \pm 0.05$ & $0.30 \pm 0.04$ & $\begin{array}{c}11.18 \pm \\
26.63\end{array}$ & $\begin{array}{c}5.86 \\
\pm \\
0.91\end{array}$ \\
\hline Tumpat & 120 & $0.80 \pm 1.27$ & $\begin{array}{c}1.12 \pm \\
1.10\end{array}$ & $\begin{array}{c}0.66 \pm \\
1.26\end{array}$ & $0.13 \pm 0.22$ & $0.02 \pm 0.26$ & $4.0 \pm 0$ & $\begin{array}{c}6.94 \\
\pm \\
0.17 \\
\end{array}$ \\
\hline Total & 454 & $0.34 \pm 0.85$ & $\begin{array}{c}0.70 \pm \\
0.98\end{array}$ & $\begin{array}{c}0.76 \pm \\
1.37\end{array}$ & $0.27 \pm 3.00$ & $0.04 \pm 0.12$ & $\begin{array}{l}5.11 \pm \\
10.32\end{array}$ & $\begin{array}{c}6.52 \\
\pm \\
0.71 \\
\end{array}$ \\
\hline
\end{tabular}

Table 2: Chemical Parameters of nine districts in Kelantan

*Mean \pm SD (Standard Deviation)

**National Standard For Drinking Water Quality for:

- Ammonia: $<1.5 \mathrm{mg} / 1$

- Nitrate: $<10 \mathrm{mg} / \mathrm{l}$

- Ferum: $<0.3 \mathrm{mg} / 1$

- Manganese: $<0.1 \mathrm{mg} / 1$

- Aluminium: $<0.2 \mathrm{mg} / \mathrm{l}$

- Turbidity: $<5$ NTU

- $\mathrm{pH}: 6.5<X<9.0$

Correlation of the violations of microbiological parameter (Total Coliform, E.coli and Salmonella species) with chemical parameters

The statistical analysis of the association between violation of microbiological and chemical parameter were done. No significant correlations were found between violation of microbiological and chemical parameters.

\section{Microbiological Analysis}

\section{Discussion}

The present study was aimed to provide information on the quality of groundwater in term of microbiological (Total Coliform, E.coli, Salmonella spp, and Vibrio spp), and chemical (Ferum, Manganese, Ammonia, Nitrate, and Aluminium) in groundwater samples collected from 454 wells scattered in 9 districts of Kelantan. Results demonstrated that 49\% (221/454) samples positive for Total Coliform, 14\% (65/454) positive for E.coli, and 3\% (13/454) positive for Salmonella spp respectively. Microbiological contamination in our groundwater samples due to certain factor such as land use for agriculture activity (K.Y Lum, 1994), poultry \& human animal waste (Chin YL et.al, 2010), and wells depth (Rahman M.M et.al, 2009).

Until now, there's still limited number of research done to obtained baseline data on groundwater quality especially in rural area of Kelantan. Similar study to access agricultural impacts on Groundwater Quality was done on 1994 by K.Y Lum (1994). This study describes the broad scale study and gives details of extent and pattern of contamination in rice and tobacco agro systems. For overall, the study showed wide fluctuations 
occur in Total Coliform populations in the groundwater of the tobacco and rice agro systems. For tobacco agro systems, out of 357 number of sample, percentage of Total Coliform violations recorded was $46.77 \%$. Meanwhile for rice agro systems, out of 404 number of sample, percentage of Total Coliform violations recorded was $42.82 \%$. This study also indicates the number of violations increase during monsoon season (September till March) (K.Y Lum, 1994). Although the current study was not a longitudinal study as research by K.Y Lum in 1994, the percentage of Total Coliform recorded was almost slightly higher 49\% (221/454). Plus, the current study extent the type of microbiological violation to other species such as E.coli, Salmonella spp, as well as Vibrio cholera. Therefore, in future, trend of analysis of these pathogens (E.coli, Salmonella spp, Vibrio cholera) in groundwater should be conducted in order to control and further offset the negative effects.

While violation of Total Coliform in groundwater can derived from agriculture activities (K.Y Lum, 1994), it also shows that violation of shallow well can be caused by surface activities such as poultry and human animal waste (Chin YL et.al, 2010). The study conducted in Pulau Tiga, Sabah, Malaysia concluded that human factor such as poor sanitation and sanitation facilities too close to the wells can contribute to Faecal Coliform contamination such as E.coli (Chin YL et al, 2010). Previous study limited on small number of samples (from five wells in Pulau Tiga, Sabah) indicates that all wells were contaminated with E.coli. Similar study also conducted in Terengganu to identify microbiological in column water. Study of column water quality in Terengganu involves seven districts: Kemaman, Dungun, Marang, Kuala Terengganu, Hulu Terengganu, Setiu, and Besut. Four samples were collected from Kuala Terengganu area and two samples each were collected from other districts (Rahman M.M et al, 2009). Both studies incorporate small number of water samples but concluded that shallow wells mostly contaminated with E.coli (Chin YL et al, 2010; Rahman M.M et al, 2009). However, the current research covers a high number of wells and the prevalence of E.coli reported only $14 \%$ (65 wells out of 454 tested positive for E.coli).

Despite cholera and typhoid outbreak that still occur in Kelantan, study on the prevalence of bacterial species that cause the disease (Vibrio cholera, and Salmonella typhii) was limited. Majority of the study conducted mainly focusing on molecular study and Genomic differentiation of Vibrio cholera and Salmonella typhii (Vimala et al, 2010; Ang et al, 2010). Vimala et al (2010) provide new information regarding the presence of Vibrio cholera and Vibrio parahemolyticus strains in various waterways in Bachok, Kelantan whilst Ang et al (2010) demonstrates presence of toxigenic Vibrio cholera O1 El Thor variant strain as causes of cholera outbreak in Kelantan via molecular evidence. With the finding of this study that shows presence of Salmonella species in 13 out of 454 samples (3\%) and no Vibrio spp detected, it can assumed that groundwater source was not the main source of typhoid and cholera outbreak in Kelantan. As reported by Ab Rahman et al (1990), cholera outbreaks in Kelantan were due to poor basic sanitation and personal hygiene with person to person transmission via food and water was the main mode of spread. The Kelantan river water and river clams were confirmed sources of reservoir during the outbreak (Ab Rahman et al, 1990). However, since the current research is not a longitudinal study, trend analysis of Vibrio spp and Salmonella spp in groundwater should be conducted to obtained real status of groundwater quality in Kelantan.

\section{Chemical Analysis:}

Groundwater was commonly known for high mineral content especially for Ferum and Manganese (Thamer et al, 2009). In 2008, a study was conducted to access quantity and quality of groundwater in fractured met sedimentary rocks of the West Coast of Peninsular Malaysia. With one of the objective to examined the quality of the groundwater and the industries that are using the water, the study found the average Ferum content in groundwater samples is $2.39 \mathrm{mg} / \mathrm{l}$ with only $19 \%$ from 66 wells tested contain Ferum lower than the Ministry of Health Drinking Water Standard of 0.3mg/l (Nasiman et al, 2011). In comparison our study found that level of Ferum is slightly lower $(0.76 \pm 1.37 \mathrm{mg} / \mathrm{l})$ with number of wells contain Ferum lower than Ministry of Health Standard was higher $61 \%$ (277/454 wells). Difference in Ferum level between these two studies was probably due to stratification in water table since our study mainly focusing on shallow wells. Nor Bakhiah et al, 2012 demonstrates difference level of mineral such as Ferum and Manganese can even occur in shallow level like Semberong Lake where stratification does take place. In our study level of Manganese also increase on par with increase level of Ferum with average Manganese content in groundwater samples is $0.28 \pm 3.01 \mathrm{mg} / \mathrm{l}$ with only 29\% (133/454 wells) contain Manganese higher than the Ministry of Health Drinking Water Standard of $0.1 \mathrm{mg} / \mathrm{l}$.

Aluminium was not one of the common chemical parameter studied in groundwater quality compared to Ferum and Manganese. As indicate in our study out of 454 groundwater samples tested; only $1 \%$ (3 groundwater samples) shows level of Aluminium higher than Ministry of Health Drinking Water Standard of $0.2 \mathrm{mg} / \mathrm{l}$ with average Aluminium level $0.04 \pm 0.12 \mathrm{mg} / \mathrm{l}$.

Ammonia and Nitrate were tested in this study to see whether agriculture and human activities on surface can affect shallow well water quality or not. As mentioned by previous study that was carried out at Ladang Merdeka Ismail Mulong Kota Bharu, average Nitrate level in paddy field was $4.81 \mathrm{mg} / 1$ with a maximum value of $17.16 \mathrm{mg} / \mathrm{l}$ (Azwan et al, 2010). Similar study was conducted involving cross sectional study 
with an aim to determine health risk of residents in an intensive agriculture area of Bachok, Kelantan from Nitrate exposure in drinking well water. Results indicate that Nitrate level was below Ministry of Health Drinking Water Standard of 10mg/l with average mean $1.66 \pm 2.11 \mathrm{mg} / \mathrm{l}$ (Jamaludin et al 2013). By comparing between these two studies our research produce low level of Nitrate with an average Nitrate value $0.70 \pm$ $0.98 \mathrm{mg} / \mathrm{l}$ and yet none of the samples tested give higher value than $10 \mathrm{mg} / \mathrm{l}$. Besides that level of Ammonia in groundwater samples tested also low compared to Maximum Concentration Limit of Ministry of Health Drinking Water Standard of $1.5 \mathrm{mg} / \mathrm{l}$ with average level $0.34 \pm 0.85 \mathrm{mg} / \mathrm{l}$. However from 454 groundwater samples tested, 29 samples (6\%) shows violation with level of ammonium higher than $1.5 \mathrm{mg} / \mathrm{l}$. Increase level of Nitrate in groundwater samples correlates with decrease level of ammonium due to increase in nitrification process in soil and groundwater (Ahmad et al 1994).

In future, it is important to include Water Quality Index (WQI) coupled with trend analysis when study groundwater quality as use by Ministry of Health in monitoring quality of Public Water Supply via Drinking Water Quality Index (DWQI). Besides that, implementation of Water Safety Plan (WSP) for rural water supply system that utilise groundwater source was important for overall control of the microbial and chemical quality of drinking water. WSP comprises system assessment and design, operational monitoring and management plans. The elements of a WSP build on the multi-barrier approach, hazard analysis and critical control points and other systematic management approach. Other suggestion for future study also to include Quantitative Microbial Risk Assessment (QMRA) approach which consist four steps (hazard identification, exposure assessment, dose - response relation and risk characterization).

\section{Conclusion}

Throughout this study 49\% (221/454) samples positive for Total Coliform, 14\% (65/454) positive for E.coli, and 3\% (13/454) positive for Salmonella spp respectively. No samples positive for Vibrio Cholera were detected. The mean concentrations of these microbial were $3176 \pm 18032 \mathrm{MPN} / 100 \mathrm{ml}$ for Total Coliform, $5.09 \pm$ $30.77 \mathrm{MPN} / 100 \mathrm{ml}$ for E.coli and $0.06 \pm 0.41 \mathrm{MPN} / 100 \mathrm{ml}$ for Salmonella spp. As for chemical parameter, violation of Ferum were detected more frequently $(39 \%)$ with mean value $0.76 \mathrm{mg} / 1 \pm 1.37$ followed by Manganese (29\%) mean value $0.27 \mathrm{mg} / \mathrm{l} \pm 3.01$, Ammonia $(6 \%)$ mean value $0.34 \mathrm{mg} / \mathrm{l} \pm 0.85$ and Aluminium (only $1 \%$ ) mean value $0.04 \mathrm{mg} / \mathrm{l} \pm 0.12$. No violation of Nitrate detected in all samples. Since coverage of public water supply in Kelantan still low compared to other states, the use of groundwater as alternative source by public is crucial thus an improved understanding of the impact in microbial and chemical in water source are very much needed. Inclusion of comprehensive Water Quality Index (WQI), comprehensive Water Safety Plan (WSP) and Quantitative Microbial Risk Assessment (QMRA) approaches will also provide a greater understanding and assurance of better groundwater quality in Kelantan.

\section{Acknowledgement}

The authors express their sincere gratitude to the staff from Health District office around Kelantan for helping in sample collection as well as staff from Food Division, Public Health Laboratory, Kota Bharu, Kelantan for helping in microbiological analysis.

\section{References}

[1]. Jamaludin, N., S.M. Sham and S.N.S. Ismail, 2013. Health Risk Assessment of Nitrate Exposure In Well Water Of Residents In Intensive Agriculture Area. Am. J. Applied Sci., 10: 442-448

[2]. Frederick, J.A, Beverly J.P, Timothy J.B, et al, 1997. A Community Waterborne Outbreak of Salmonellosis and The Effectiveness of a Boil Water Order. Am. J. Public Health, 87: 580-584

[3]. Hrudey, S.E, P. Payment, P. M. Huck, et al, 2003. A Fatal Waterborne Disease Epidemic in Walkerton Ontario: Comparison With Other Waterborne Outbreaks In The Developed World. Water Science and Technology, 47: 7-14

[4]. Arokiasamy J.T, 1996. Microbial Diseases in Malaysia: Recent Experiences. Medical Journal of Malaysia, 51: 4-11

[5]. Ab Rahman Isa, 1990. Cholera Outbreak in Tumpat, Kelantan - 1990. Medical Journal of Malaysia, 45: 187-193

[6]. Ang, G. Y, Choo Y. Y, Kamarudin Balqis, et al, 2010. Molecular Evidence of Cholera Outbreak Caused By a Toxigenic Vibrio Cholerae O1 El Tor Variant Strain in Kelantan, Malaysia. Journal of Clinical Microbiology, 48: 3963-3969

[7]. Thamer A. M, Abdul H. G, 2009. Evaluation of Yield And Groundwater Quality For Selected Wells in Malaysia. Pertanika Journal of Science \& Technology, 17: 33-42

[8]. Mohamad Roslan M. K, Mohd Kamil Y, Wan Nor Azmin S, et al, 2007. Creation of a Ground Water Quality Index for an Open Municipal Landfill Area. Malaysian Journal of Mathematical Sciences, 2: 181-192

[9]. Mohamed Azwan M. Z, Mohd Kamil Y, Hazilia H, et al, 2010. Nitrate-Nitrogen Concentration Variation In Groundwater Flow In A Paddy Field. Journal = The Institution of Engineers, Malaysia, 71: 2-10

[10]. Rohazaini M. J, Mohamad N. S, and Mohd Nadzri M. R, 2011. Geostatics Approach With Indicator Kriging For Assessing Groundwater Vulnerability To Nitrate Contamination. $7^{\text {th }}$ ESRI Asia Pacific User Conference \& $21^{\text {st }}$ Korean GIS Conference: $15-16$ 2011

[11]. K. Y. Lum, 1994. Microbial Contamination of Water Resources In The Kelantan Plain. The Australian Centre for International Agricultural Research (ACIAR) Proceedings (Agricultural Impacts on Groundwater Quality), 24-27 October 1994: 29-32

[12]. Nasiman Sapari, Raja Zainariah R. A, and Hisyam Jusoh, 2011. Quantity and Quality of Groundwater in Fractured Metasedimentary Rocks of The West Coast of Peninsular Malaysia. Sains Malaysiana, 40: 537-542 
[13]. Jaafar N. J, Yuan X. G, Nur Fatihah M. Z, et al, 2013. Epidemiological Analysis of Typhoid Fever in Kelantan From a Retrieved Registry. Malaysian Journal of Microbiology, 9: 147-151

[14]. R Ahmad, M. Zulkefli, M. Ahmed et al, 1994. Environmental Impact of Agricultural Inorganic Pollution on Groundwater Resources of The Kelantan Plain. The Australian Centre for International Agricultural Research (ACIAR) Proceedings (Agricultural Impacts on Groundwater Quality), 24-27 October 1994: 8-21

[15]. Ismail Mohamed, 2004. A Study Of The Groundwater Quality In Pasir Puteh District Kelantan. University Putra Malaysia, Thesis Master of Science

[16]. Vimala B, Thong K. L and Chong V. C, 2010. Isolation, Detection and Genomic Differentiation of Vibrio cholera and Vibrio parahaemolyticus in Bachok, Kelantan. Malaysian Journal of Science, 29: 1-10

[17]. Chin Y. L, Mohd Harun A, Baba Musta et al, 2010. Assessment of Selected Chemical and Microbial Parametersin Groundwater of Pulau Tiga, Sabah, Malaysia. Sains Malaysiana, 39: 337-345

[18]. Rahman M. M, Nazroon and W. B. W. Nik, 2009. Microbiological Examination of Column Water In Terengganu. The Malaysian Journal of Analytical Sciences, 13: 136-140

[19]. Pruss-Ustun A, Bos R, Gore F, Bartam J, 2008. Safe Water, Better Health: Costs, Benefits And Sustainability Of Interventions To Protect And Promote Health. World Health Organization, Geneva

[20]. World Health Organization (WHO), 1999. World Health Report 1999. World Health Organization, Geneva

[21]. Swerdlow D. L, Woodruff B. A, Brady R. C, et al, 1992. A Waterborne Outbreak In Missouri of Escherichia coli O157:H7 Associated With Bloody Diarrhoea And Death. Annals of Internal Medicine, 117: 812-819

[22]. Malik A. S and Malik R. H, 2001. Typhoid Fever In Malaysian Children. Medical Journal of Malaysia, 56: 478-490

[23]. Lin F. Y, Vo A. H, Phan V. B et al, 2000. The Epidemiology Of Typhoid Fever In The Dong Thap Province, Mekong Delta Region Of Vietnam. American Journal of Tropical Medicine and Hygiene, 62: 644-648

[24]. Hamzah W. M, Nor M. F and Husin H. M, 2011. Kelantan Typhoid Initiative: Lesson Learnt. Malaysian Journal of Public Health Medicine, 11 (Suppl 3), 6

[25]. World Health Organization (WHO), 2011. Guidelines For Drinking Water Quality $4^{\text {th }}$ Edition. World Health Organization, Geneva

[26]. Ministry Of Health, 2005. Drinking Water Quality Standard. http://kmam.moh.gov.my/public-user/drinking-water-qualitystandard.html. Accessed 31 December 2013

[27]. Lwanga S. K, Lemeshow S, 1991. Sample Size Determination In Health Studies: A Practical Manual. World Health Organization. Geneva. http://apps.who.int/iris/bitstream/10665/40062/1/9241544058_\%28p1-p22\%29.pdf. Accessed 3 January 2013

[28]. AOAC Official Method 991.14: Coliform and Escherichia coli Counts in Foods. http://www.longrunbio.com/uploads/soft/130814/1-130Q4144244.pdf. Accessed 3 January 2013

[29]. Nor Bakhiah B, Zulkifli Y, Muhamad Askari et al, 2012. Preliminary Results Of Stratification Study In Sembrong Reservoir, Peninsular Malaysia. University Malaya, http://umexpert.um.edu.my/file/publication/00004094_92640.pdf Accessed 31 December 2013 